\title{
IMMUNOHISTOCHEMICAL DETECTION OF ESTROGEN RECEPTORS IN CANINE MAMMARY TUMORS
}

\author{
Elena Atanaskova Petrov ${ }^{1}$, Ivica Gjurovski², Trpe Ristoski ${ }^{2}$, Goran Nikolovski ${ }^{1}$, \\ Pandorce Trenkoska ${ }^{3}$, Plamen Trojacanec ${ }^{4}$, Ksenija Ilievska ${ }^{4}$, \\ Toni Dovenski ${ }^{5}$, Gordana Petrushevska ${ }^{6}$ \\ ${ }^{1}$ Department of Internal Medicine of Small Animals, \\ Faculty of Veterinary Medicine, Ss. Cyril and Methodius University in Skopje, Macedonia \\ ${ }^{2}$ Department of Pathology, Faculty of Veterinary Medicine, \\ Ss. Cyril and Methodius University in Skopje, Macedonia \\ ${ }^{3}$ Veterinary Clinic D-r Naletoski, Str. 1244/3, Skopje, Macedonia \\ ${ }^{4}$ Department of Surgery, Faculty of Veterinary Medicine, \\ Ss. Cyril and Methodius University in Skopje, Macedonia \\ ${ }^{5}$ Department of Reproduction, Faculty of Veterinary Medicine, \\ Ss. Cyril and Methodius University, Skopje, Macedonia \\ ${ }^{6}$ Department of Pathology, Medical Faculty, \\ Ss. Cyril and Methodius University in Skopje, Macedonia
}

Received 17 August 2015; Received in revised form 21 December 2015; Accepted 4 January 2016

\begin{abstract}
Mammary tumors are among the most common neoplasms in intact female dogs. They have a complex morphology, usually affecting middle age and older bitches. Almost 50\% of the mammary tumors in dogs are malignant neoplasms. Prognosis is based on several factors: stage, age, tumor size, metastasis, histopathology, ovariectomy status and hormone-receptor activity. Immunohistochemical (IHC) measurement has become increasingly an important diagnostic and prognostic parameter, with the development of monoclonal antibodies against nuclear estrogen and progestin receptors. The aim of this study was to detect the presence of ER receptors in malignant canine mammary tumors and to identify their association with the clinical course of the tumor. Mammary tumor samples have been obtained by mastectomy from dogs presented at our clinic. Detailed clinical examination, $\mathrm{CBC}$ and basic serum biochemical profile were performed in all patients. Surgery was the only treatment. Histopathological examination and immunohistochemical detection of estrogen $\alpha$ receptors (ER $\alpha$ ) was performed on 8 formalin-fixed, paraffin-embedded tissue samples, using the PT LINK immunoperoxidase technique. Histopathological examination of the mammary tumor samples $(n=11)$ revealed tubular adenocarcinoma $(n=6,54.5 \%)$ and ductal adenocarcinoma $(\mathrm{n}=3,27.3 \%)$, one patient with benign adenoma and one with mastitis. Patients with positive ER tumors are alive, without remission, while 3 of the patients that were ER negative died due to lung metastases. According to our results, it can be concluded that the appearance and development of canine mammary tumors is highly connected with ovarian steroid hormones and that immunostaining of the tumors may be used as a good prognostic parameter in these patients.
\end{abstract}

Key words: dog, mammary tumor, histopathology, immunohistochemy, ER $\alpha$ receptors

\section{INTRODUCTION}

Canine mammary tumors are the most prevalent tumors in female dogs, representing around $42 \%$ of all tumors $(1,2)$. These neoplasms have a complex morphology - epithelial, mixed, and mesenchymal types (3).

Corresponding author: Prof. Toni Dovenski, $\mathrm{PhD}$

E-mail address: dovenski@fvm.ukim.edu.mk

Present address: Faculty of Veterinary Medicine, Ss. Cyril and Methodius

University in Skopje, Str. Lazar Pop Trajkov 5-7, Skopje, Macedonia Phone: ++38923240767

Copyright: (C) 2016 Atanaskova Petrov E. This is an open-access article published under the terms of the Creative Commons Attribution License which permits unrestricted use, distribution, and reproduction in any medium, provided the original author and source are credited. Competing Interests: The authors have declared that no competing interests exist.

Available Online First: 18 January 2016

Published on: 15 March 2016

http://dx.doi.org/10.1515/macvetrev-2016-0073
Most frequently mammary gland tumors are found in 5 years and older bitches (4). Mostly affected parts are the caudal abdominal and inguinal mammary glands. Fifty to almost $70 \%$ of dogs with mammary tumors have multiple tumours $(2,4,5)$. When multiple tumors are present, different tumour types may be found in one patient. According to some studies $50 \%$ of the tumors are malignant; most of them are carcinomas (6).

Histologic diagnosis of cancer does not always imply a malignant clinical course. Reliable prognostic factors are necessary for evaluation of the individual risk for undesirable clinical result. There are some prognostic factors of malignant mammary tumors in dogs and these include: tumor size, lymph node status, histologic type, histologic 
malignancy grade, degree of nuclear differentiation and distant metastasis (7).

Although several studies have been carried out on the prognostic aspects of canine mammary neoplasms, some areas, especially the role of steroid hormone receptors, remain uncertain (8).

Estrogens and progesterone excreted from the ovary have an impact on mammary gland tissue and presents a risk factor associated with the development of mammary tumors. According to many studies preventive effect of sterilization has been reported. The relative risk for mammary neoplasms in female dogs spayed before the first estrous is $0.5 \%$, after the first cycle $8 \%$, after the second cycle $26 \%$; with the protective effect being lost after about 4 cycles $(9,10)$. Beauvais et al. (11) analyzed these conclusions and they found that the data are limited with a risk of bias, so further investigations are necessary in order to confirm that statement.

When metastases are present, dogs may show nonspecific symptoms such as fatigue, lethargy, weight loss, dyspnoea, cough, lymphoedema or lameness. Clinical signs depend on the extent and location of the metastases which determines the occurrence and severity of the clinical signs $(2,5)$.

Prognosis depends on many factors (stage, age, tumor size, metastasis, histopathology, ovariectomy status and hormone-receptor activity). With the development of monoclonal antibodies against nuclear estrogen and progestin receptors, immunohistochemical (IHC) measurement has become increasingly important (12).

The occurrence and growth of most mammary gland carcinomas is estrogen dependent. Benign tumors and well-differentiated tumors are more likely to be ER-positive, whereas undifferentiated, anaplastic tumors are usually ER-negative (8). The level of progesterone receptors (PR) is used as marker for hormone responsiveness of the tumor and patient's prognosis. PR-negative neoplasms generally have worse prognosis than progesterone receptor-positive neoplasms (13).

The aim of the present study was to detect the presence of ER receptors in malignant canine mammary tumors and to identify its association with clinical course of the tumor.

\section{MATERIAL AND METHODS}

Thirteen mammary tumor samples have been obtained by mastectomy from female dogs (6-13 years old, none of them were spayed) presented at the University Veterinary Hospital at the Faculty of Veterinary Medicine-Skopje. Medical history analyses showed that the first appearance of the tumor masses was noticed in a period of 1 month to one year before admission to the hospital and none 118 of the patients were spayed. Rigorous examination was performed: assessment of the general condition, temperature, pulse, respiration, lymph node palpation, $\mathrm{CBC}$ and basic serum biochemical profile.

Surgical removal of the masses was the only treatment, with additional ovariohisterectomy in 7 patients. Following surgical excision, tissue samples were fixed in 10\% formaldehyde, dehydrated, embedded in paraffin, then cut into $4 \mu \mathrm{m}$ sections, and stained with hematoxylin and eosin (Merck, Darmstrad, Germany). All of the tumours were histologically classified into these categories: malignant tumours, benign tumours, unclassified tumours, and mammary hyperplasia/dysplasia (14).

Immunohistochemical detection of ER $\alpha$ was performed on 8 formalin-fixed, paraffinembedded tissue samples. The procedure was performed on paraffin sections using the PT LINK immunoperoxidase technique (DakoChemMate, Denmark). For determination of ER $\alpha$ receptor expression, we used monoclonal antibody anti-ER from DAKO.

Corresponding positive and negative control were used. Two human score systems were used: ERi24, 45 and ERp. The ERi score was calculated as $\mathrm{P}_{1}+\left(2 * \mathrm{P}_{2}\right)+\left(3 * \mathrm{P}_{3}\right)$ where $\mathrm{P}_{1}, \mathrm{P}_{2}$, and $\mathrm{P}_{3}$ are the estimated percentages of positive nuclei with low $\left(\mathrm{P}_{1}\right)$, medium $\left(\mathrm{P}_{2}\right)$, and high $\left(\mathrm{P}_{3}\right)$ intensity of immunostaining. The ERp score considered only the percentage of positive cells independent of the grade of intensity.

\section{RESULTS}

Most of the patients (11 out of 13) with mammary tumors were $12-13$ years old. From a reproductive aspect, nine of the patients with malignant mammary tumors $(81.8 \%)$ never had a litter and were not treated with exogenous hormones. Only one patient had history of false pregnancies after every oestrus cycle. Multiple nodular tumors were found in 9 patients, and solitary tumor in 4 patients (Fig. 1).

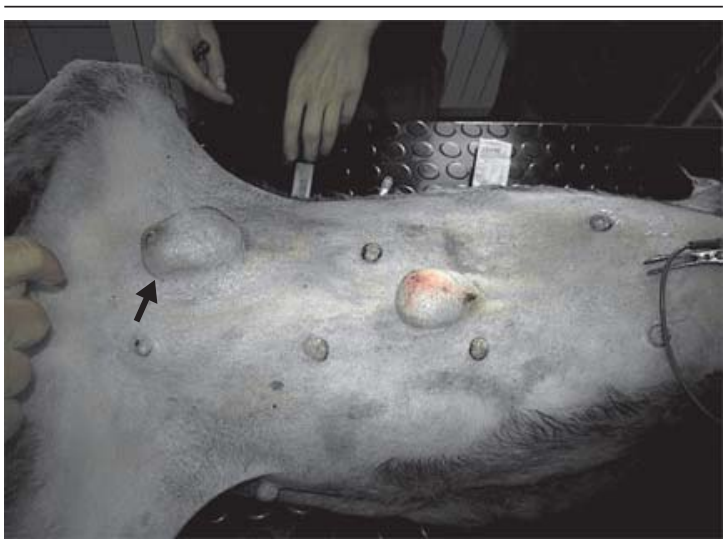

Figure 1. Solitary canine mammary tumor 
Immunohistochemical detection of estrogen receptors in canine mammary tumors

Histopathology report made on 11 samples showed that six bitches had tubuloalveolar adenocarcinoma, three had ductal adenocarcinoma, there was one patient with benign adenoma and one with mastitis (Fig. 2). X-ray imaging was performed in 9 patients with diagnosed adenocarcinoma and 3 of them had lung metastases.

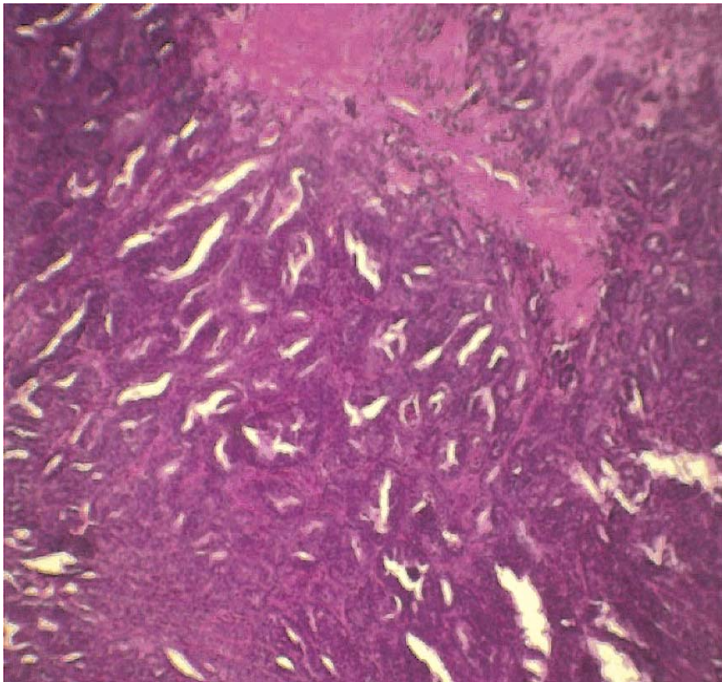

Figure 2. Histopathology of mammary adenocarcinoma

Eight malignant mammary tumors were immunohistochemically processed for ER analysis (Fig. 3). Four of the neoplasms (50\%) were ER negative (Table 1).
Table 1. Immunostaining percentage of ER and PR in different mammary tumors

\begin{tabular}{ll}
\hline Tumor type & ER $\boldsymbol{\alpha} \%$ \\
\hline Adenocarcinoma- grade II-244 & - \\
Adenocarcinoma- grade I- 241 & $20 \%$ \\
Adenocarcinoma - grade I-238 & $30 \%$ \\
Fibrosarcoma- grade III-237 & - \\
Adenocarcinoma- grade III-233 & - \\
Adenocarcinoma- grade I-223 & $30 \%$ \\
Ductal adenocarcinoma- grade II-193 & $2 \%$ \\
Adenocarcinoma - grade III194 & - \\
\hline
\end{tabular}

In addition to the surgical removal of the tumors in seven patients, ovariohysterectomy was performed. Uterine enlargement characterized as Cystic Endometrial Hyperplasia (CEH) was noted in five patients with mammary tumors (Fig. 3), histopathology confirmed diagnosis of $\mathrm{CEH}$.

Due to metastasis, two of the patient died two months after mastectomy (without ovariectomy) and one after one year. The others $(n=9)$ were controlled on a monthly basis. Six months after the treatment, these patients remained in good body condition, without any signs of health disorders. All of the patients with positive ER tumors are still alive, without remission. Three of the patients that were ER negative died due to lung metastases. Two of them (died 2 months after surgery) were presented in the Hospital with sings of dyspnoea due to lung metastases, anorexia, vomiting, decreased body temperature and lethargy. Third patient had remission six months after the surgical removal of the tumor and was euthanized six months later due to deterioration of the clinical condition.
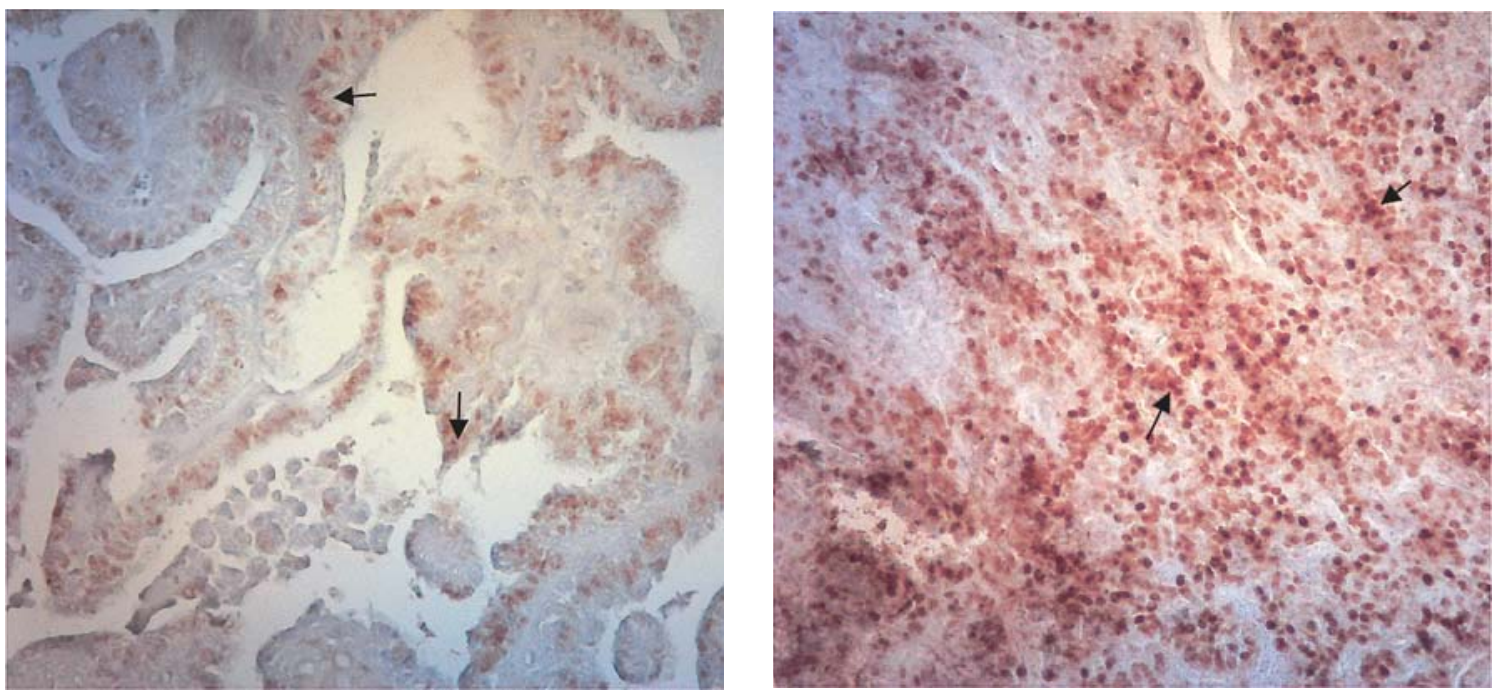

Figure 3. Canine mammary adenocarcinoma showing expression of ER $\alpha$ in the nucleus of epithelial cells (IHC x40) 


\section{DISCUSSION}

Ovarian steroids have proliferative effect on mammary epithelium that creates conditions for neoplastic proliferations. During the long luteal phase of the estrous cycle, mammary tissue is exposed to high concentrations of progesterone $(10,16)$. Mammary epithelial growth, proliferation and differentiation are regulated by the estrogen receptors (ER) and the complex cellular interactions that are mediated by a multitude of ligands, cofactors, and other stimuli. These receptors are also important for the physiological development and function of the mammary gland, but also play a role in the development and growth of mammary cancer (17). In our case 4 adenocarcinomas (50\%) had positive ER immunostaining. Compared to the histopathology grade of the tumor, $3(75 \%)$ were staged as grade I and one was grade II. Patients that had positive ER tumors are still alive and without remission, while $3(75 \%)$ of the patients that were ER negative and histopathology grade III died within 20 days to one year after intervention due to metastases. Tumors which are positive for ER or PR or both, have a better prognosis than those that are negative for both receptors (18). Both ER and PR receptors were found in normal mammary tissues and benign tumors, but less common or absent in primary cancers and distant metastases. This is due to hormonal independency of the malignant mammary tumors $(19,20,21)$.

The connection of uterine cystic glandular hyperplasia, pyometra and endocrine imbalance has been reported long time ago. Also the influence of progestogens on the development of canine mammary tumors and other nodular mammary changes has been reported (13). In our study, 5 patients with mammary tumors had cystic endometritis. Repeated progesterone influence during each metoestrus in cycling bitches leads to the gradual development of $\mathrm{CEH}$, fluid accumulation and/or bacterial infection, with the most severe end stage being pyometra. Progesterone, especially after previous oestrogen influence, contributes to the development of disease because the influence of this hormone renders the uterus susceptible to bacterial infection and pyometra $(22,23)$. There are contradictory results regarding the benefit of ovariectomy performed together with mastectomy as well as the connection of abnormal oestrous cycle, false pregnancy, pregnancy, number of litters etc. to development of canine mammary tumors (12, $15,24)$. Nine of our patient with mammary tumors had never whelped, one had one litter and one was with unknown history. False pregnancies were noted only in one patient with mammary tumors.

\section{CONCLUSION}

According to our study, with regard to other researches we can conclude that the appearance and development of mammary tumors in dogs is highly connected with ovarian steroid hormones and that positive immunohistochemical expression of the ER-s in tumors may be used as a good prognostic parameter in patients with mammary tumors.

\section{REFERENCES}

1. Moulton, J.E. (1990). Tumors of the mammary gland. In: Moulton J.E. (Ed.), Tumours in domestic animals (pp. 518-552). Berkeley: University of California Press.

2. Sorenmo, K. (2003). Canine mammary gland tumors. Vet Clin North Am Small Anim Pract. 33, 573-596. http://dx.doi.org/10.1016/S0195-5616(03)00020-2

3. Hellmen, E. (2005). Complex mammary tumours in the female dog: a review. Journal of Dairy Research 72, 90-97.

http://dx.doi.org/10.1017/S002202990500124X PMid:16180726

4. Sorenmo, K.U., Kristiansen, V.M., Cofone, M.A., Shofer, F.S., Breen, A.M., Langeland, M., Mongil, C.M., Grondahl, A.M., Teige, J., Goldschmidt, M.H. (2009). Canine mammary gland tumours: a histological continuum from benign to malignant, clinical and histopathological evidence. Vet Comp Oncol. 7, 162-172.

http://dx.doi.org/10.1111/j.1476-5829.2009.00184.x PMid:19691645

5. Misdorp, W. (2002). Tumors of the mammary gland. In: Meuten D.J. (Ed.), Tumors in domestic animals (pp. 575-606). Ames: Iowa State Press. http://dx.doi.org/10.1002/9780470376928.ch12

6. MacEwen, E.G., Withrow, S. (1996). Tumors of the mammary gland. Small Animal Oncology (pp. 356-372). Philadelphia: Saunders Company.

7. De Las Mulas, J. M., Millán, Y., Dios, R. (2005). A prospective analysis of immunohistochemically determined estrogen receptor $\alpha$ and progesterone receptor expression and host and tumor factors as predictors of disease-free period in mammary tumors of the dog. Veterinary Pathology Online 42 (2): 200-212.

http://dx.doi.org/10.1354/vp.42-2-200 PMid:15753474

8. Nieto, A., Pena, L., Pérez-Alenza, M. D., Sanchez, M. A., Flores, J.M., Castano, M. (2000). Immunohistologic detection of estrogen receptor alpha in canine mammary tumors: clinical and pathologic associations and prognostic significance. Vet Pathol. 37 (3): 239-247.

http://dx.doi.org/10.1354/vp.37-3-239

PMid:10810988 
9. Lana, S.E., Rutteman, G.R., Withrow, S.J. (2007). Tumors of the mammary gland. In: Withrow S.J \& MacEwen B.R. (Ed.), Small animal clinical oncology (pp. 455-477). Philadelphia: Saunders Company. http://dx.doi.org/10.1016/B978-072160558-6.50029-0

10. Murphy, S. (2008). Mammary tumours in dogs and cats. Inpractice 6, 334-339. http://dx.doi.org/10.1136/inpract.30.6.334

11. Beauvais,W., Cardwell, J. M., Brodbelt, D. C. (2012). The effect of neutering on the risk of mammary tumours in dogs - a systematic review. J Small Anim Pract. 53, 314-322. http://dx.doi.org/10.1111/j.1748-5827.2011.01220.x PMid:22647210

12. Las Mulas, J.M., Millan, Y., Dios R. (2005). A prospective analysis of immunohistochemically determined estrogen receptor alpha and progesterone receptor expression and host and tumor factors as predictors of disease-free period in mammary tumors of the dog. Vet Pathol. 42, 200-212.

http://dx.doi.org/10.1354/vp.42-2-200

PMid:15753474

13. Cork, D. M. W., Lennard, T. W. J., Tyson-Capper, A. J. (2008). Alternative splicing and the progesterone receptor in breast cancer. Breast Cancer Res. 10 (3): 207.

http://dx.doi.org/10.1186/bcr2097

PMid:18557990 PMCid:PMC2481493

14. Misdorp, W., Hellmen, E., Else, R.W. (1999). Mammary tumours and dysplasia in dogs and cats. Histologic classification of tumours of domestic animals. Second series (pp. 3-6). Washington DC: Armed Forces Institute of Pathology.

15. Sorenmo, K.U., Shoferm, F.S., Goldschmidt, M.H. (2000). Effect of spaying and timing of spaying on survival of dogs with mammary carcinoma. J Vet Intern Med. 14, 266-270.

http://dx.doi.org/10.1111/j.1939-1676.2000.tb01165.x PMid:10830539

16. Thuroczy, J., Reisvaag, G. J. K., Perge, E., Tibold, A., Szilagyi, J., Balogh, L. (2007). Immunohistochemical detection of progesterone and cellular proliferation in canine mammary tumours. J Comp Pathol. 137 (2-3): 122-129.

http://dx.doi.org/10.1016/j.jcpa.2007.05.005

PMid: 17645888

17. Diaz, L. K., Sneige, N. (2005). Estrogen receptor analysis for breast cancer: current issues and keys to increasing testing accuracy. Adv Anat Pathol. 12 (1): $10-19$. http://dx.doi.org/10.1097/00125480-200501000-00003 PMid: 15614160
18. Port Louis, L.R., Varshney, K.C., Nair, M.G. (2012). An immunohistochemical study on the expression of sex steroid receptors in canine mammary tumors. ISRN VetSci. 1-7.

http://dx.doi.org/10.5402/2012/378607

PMid:23738123 PMCid:PMC3658582

19. Rutteman, G.R., Misdorpl, W., Blankenstein, M.A., Van den Brom, W.E. (1988). Oestrogen (ER) and progestin receptors (PR) in mammary tissue of the female dog: Different receptor profile in nonmalignant and malignant states. Br J Cancer. 58, 594-599. http://dx.doi.org/10.1038/bjc.1988.266 PMid:3219269 PMCid:PMC2246835

20. Mariotti, F., Giacomo, R., Subeide, M. (2013). Immunohistochemical evaluation of ovarian hormonal receptors in canine mammary tumors. Open J Vet Med. 3, 104-110. http://dx.doi.org/10.4236/ojvm.2013.32017

21. Spoerri, M., Guscetti, F., Hartnack, S., Boos, A., Oei, C., Balogh, O., Nowaczyk, R. M., Michel, E., Reichler, I. M., Kowalewski, M. P. (2015). Endocrine control of canine mammary neoplasms: serum reproductive hormone levels and tissue expression of steroid hormone, prolactin and growth hormone receptors. BMC Vet Res. 11, 235. http://dx.doi.org/10.1186/s12917-015-0546-y PMid:26370564 PMCid:PMC4570623

22. Chen, Y.M., Lee, C.S., Wright, P.J. (2006). The roles of progestagen and uterine irritant in the maintenance of cystic endometrial hyperplasia in the canine uterus. Theriogenology 66, 1537-1544.

http://dx.doi.org/10.1016/j.theriogenology.2006.01.019 PMid:16472854

23. Hagman, R. (2014). Diagnostic and prognostic markers for uterine diseases in dogs. Reprod Dom Anim. 49 (2): 16-20. http://dx.doi.org/10.1111/rda.12331 PMid:24947856

24. Queiroga, F.L., Perez- Alenza, M.D., Silvan, G., Pena, L., Lopes, C., Illera, J.C. (2005). Role of steroid hormones and prolactin in canine mammary cancer. $\mathrm{J}$ Steroid Biochem Mol Biol. 94, 181-187. http://dx.doi.org/10.1016/j.jsbmb.2004.12.014 PMid:15862964 